\title{
ISOLASI CENDAWAN ENDOFIT DARI AKAR WANGI (Vetiveria zizanioides L.) DAN POTENSINYA SEBAGAI ANTIMIKROBA
}

\author{
Israwati Harahap dan Elsie
}

\author{
Program Studi Biologi, Fakultas MIPA dan Kesehatan \\ Universitas Muhammadiyah Riau \\ Jln. Tuanku Tambusai Ujung No. 1 Pekanbaru 28285 \\ e-mail: israwatiharahap@umri.ac.id
}

\begin{abstract}
Endophytic fungi are microorganisms living in healthy tissue of their host plants without causing disease. Endophytic fungi live in every plant, including Vetiveria zizanioides L. medicinal plant intracellulary and/or intercellulary. This plant was screened pharmacologically for antibacterial, antifungal, anticataleptic, analgesic and anti-inflammatory, rheumatism, anti oxidant and anti arthritic activity. This research aimed to isolation endophytic fungi from $V$. zizanioides L. and to screening their antimicrobial potency against microflora Escherichia coli, Staphylococcus aureus, and Candida albicans. Endophytic fungi isolation from $V$. zizanioides $L$. was done by surface sterilization method. A total of 33 isolates were recovered from 88 leaves and 88 root segments. Based on antimicrobial activity test, most of the fungal extracts showed in vitro inhibition of microbes growth.
\end{abstract}

Keywords: Endophytic fungi; Vetiveria zizanioides L.; Antimicrobial

\section{PENDAHULUAN}

Resistensi bakteri terhadap antibiotik telah menjadi masalah global yang serius. Berdasarkan laporan terakhir dari Badan Kesehatan Dunia (WHO) menunjukkan bahwa Asia Tenggara memiliki angka tertinggi dalam kasus resistensi antibiotik di dunia, khususnya infeksi yang disebabkan oleh Staphylococcus aureus yang resisten terhadap metisilin, sehingga mengakibatkan menurunnya fungsi antibiotik tersebut (www.depkes.go.id). Di Indonesia, sekitar 135.000 kematian per tahun diakibatkan karena resistensi antibiotik. Munculnya resistensi antibiotik pada bakteri patogen menuntut adanya penemuan obat baru yang lebih efektif dengan toksisitas yang rendah.

Eksplorasi untuk mendapatkan jenis antibiotik baru masih sangat diperlukan baik lewat sintesis kimia, biokimia baru maupun penemuan isolat mikrobia baru. Dalam dua dekade ini, mikroorganisme endofit merupakan salah satu sumber utama penghasil antibiotik baru. Endofit merupakan mikroorganisme yang hidup dalam jaringan tumbuhan, setidaknya satu bagian dari siklus hidupnya tanpa menyebabkan gejala penyakit (patogen) pada inangnya (Petrini 1991). Mikroorganisme endofit dapat berupa cendawan, bakteri dan aktinomiset. Hampir semua jenis tumbuhan merupakan inang bagi satu atau lebih endofit (Tan \& Zou 2001).

Cendawan endofit mampu menghasilkan senyawa metabolit sekunder yang sama dengan inangnya (Petrini et al. 1992). Produk metabolit sekunder dapat berfungsi sebagai antimikroba (Lu et al., 2000), antifungi dan sitotoksik (Santiago, 2011), antivirus, antikanker, antidiabetes, antimalaria, antioksidan dan antiimmunosupresif (Strobel dan Daisy, 2003). Selain itu, cendawan endofit berperan dalam melindungi inangnya terhadap hama serangga (Azevedo et al., 2006), zat pengatur tumbuh (Tan dan Zou, 2001), penghasil enzim-enzim hidrolitik seperti amilase, selulase, xilanase, ligninase (Choi et al., 2005) dan kitinase (Zinniel et al., 2002).

Penelitian tentang cendawan endofit dari berbagai jenis tanaman obat telah banyak dilakukan diantaranya oleh Hsiao et al. (2016) telah melakukan isolasi senyawa metabolit sekunder cytochalasan yang bersifat antiinflammatory dari cendawan endofit Phomopsis theicola BCRC asal tanaman endemik Taiwan Litsea hypophaea. Martin \& James (2015) melakukan isolasi cendawan endofit dari rumput disepanjang pesisir Oregon dan memperoleh cendawan endofit yaitu Penicillium sp., Phlebia sp. Heterobasidium sp. Phaeosphaeria sp. dan 
Aureobasidium sp. yang memperlihatkan aktivitas dalam menghambat pertumbuhan Bacillus sp. Sejauh ini belum ada data mengenai cendawan endofit yang dilaporkan berasal dari Akar wangi (Vetiveria zizanioides L.).

Akar wangi (Vetiveria zizanioides L.) merupakan tanaman aromatik yang banyak digunakan untuk mengobati berbagai macam penyakit. Berdasarkan analisis fitokimia dari ekstrak akar wangi diketahui memiliki kandungan alkaloid, asam amino, flavonoid, saponin dan tanin (Ratha et al. 2012) yang bermanfaat sebagai agen antifungi, antioksidan dan antibakteri (Moffitt et al. 2002). Soni et al. (2015) menguji ekstrak akar wangi terhadap 9 isolat bakteri dan 4 isolat cendawan. Hasilnya menunjukkan bahwa ekstrak akar wangi mampu menghambat pertumbuhan Staphylococcus aureus dengan zona hambat sebesar $15 \pm 0,12 \mathrm{~mm}$

Penelusuran dan pemanfaatan senyawa aktif dari akar wangi masih terbatas dalam isolasi senyawa yang dihasilkan oleh akar wangi tersebut sehingga akan membutuhkan banyak biomassa. Oleh karena itu, cara yang efisien untuk memperoleh senyawa bioaktif tersebut adalah dengan menggunakan cendawan endofit. Besar kemungkinan cendawan endofit yang menetap pada akar wangi tersebut memiliki kemampuan untuk mensintesis senyawa antimikroba yang sama seperti tanaman inangnya.

\section{METODOLOGI PENELITIAN}

\section{Alat dan Bahan}

Alat yang digunakan dalam penelitian antara lain Laminar Air Flow (LAF) oven (Memmert), inkubator (Memmert), autoklaf (All American), kompor listrik, timbangan digital, spatula, batang pengaduk, cawan Petri, bunsen, pipet volume, gelas ukur, gunting, jarum ose, mikropipet dan Tip, shaking incubator, sedotan steril, spritus, tisu, plastic wrap, alumunium foil, cotton swab, kapas, sarung tangan, masker serta alat-alat gelas.

Bahan yang digunakan yaitu akar dan daun tanaman akar wangi (V. zizanioides L.), Bakteri target (Staphylococcus aureus dan Escherichia coli), cendawan target (Candida albicans), Malt Extract Agar (MEA), Potato Dextrose Yeast
(PDY), Potato Dextrose Agar (PDA), Potato Dextrose Broth (PDB), Nutrient Agar (NA), Nutrient Broth (NB), aquades steril, alkohol 70\%, natrium hipoklorit $(\mathrm{NaOCl}) 5,3 \%$, dan antibiotik kloramfenikol.

\section{Pengambilan Sampel}

Sampel tanaman akar wangi ( $V$. zizanioides L.) diambil dari perumahan warga yang terletak di Kecamatan Rumbai Pesisir, Pekanbaru.

\section{Prosedur Kerja}

Isolasi Cendawan Endofit

Isolasi cendawan endofit dilakukan dengan mengacu pada Okane et al. (2008) dengan modifikasi. Isolasi cendawan endofit dari tanaman akar wangi dimulai dengan mengoleksi tanaman dari lapangan selanjutnya dibersihkan dari kotoran dengan cara mencucinya di bawah air mengalir. Bagian akar dan daun tanaman akar wangi dipotong secara aseptik dengan pisau menjadi potongan-potongan berukuran $\pm 1 \mathrm{~cm}$. Potongan akar dan daun tersebut disterilisasi dengan cara direndam didalam larutan alkohol 70 $\%$ selama 1 menit, natrium hipoklorit 5,3\% selama 5 menit, dan terakhir dengan alkohol selama 30 detik. Setelah itu, potongan akar dan daun tersebut dibilas dengan aquades sebanyak 3 kali. Sampel akar dan daun diinokulasi di dalam cawan Petri yang sudah berisi medium MEA. Setiap cawan Petri berisi 4 potong akar atau daun. Masing-masing sampel diinokulasi dengan 3 kali pengulangan. Sebagai kontrol, aquades bilasan terakhir diambil $\pm 1 \mathrm{ml}$ dan dituang ke dalam medium MEA secara spread plate. Sampel tanaman yang sudah diinokulasi, selanjutnya diinkubasi pada suhu $25-30{ }^{\circ} \mathrm{C}$ selama 5-7 hari atau sampai cendawan tumbuh

Produksi Senyawa Antimikroba dari Cendawan Endofit

Setiap isolat cendawan endofit yang tumbuh pada media PDA diambil sebanyak 6 potongan dengan menggunakan sedotan steril dan dimasukkan ke dalam tabung reaksi yang sudah berisi $10 \mathrm{ml}$ media Potato Dextrose Broth (PDB). Kemudian diinkubasi di dalam shaking incubator selama 21-28 hari dengan kecepatan $120 \mathrm{rpm}$ dan suhu $28^{\circ} \mathrm{C}$. 


\section{Persiapan Mikroba Uji}

Sebanyak satu ose koloni Candida albicans diinokulasikan ke dalam tabung reaksi yang sudah berisi $10 \mathrm{ml}$ media Potato Dextrose Yeast (PDY) cair, kemudian diinkubasi pada suhu ruang selama 18-24 jam. Sebanyak satu ose koloni Staphylococcus aureus dan Escherichia coli diinokulasikan ke dalam masing-masing tabung reaksi yang sudah berisi $10 \mathrm{ml}$ media Nutrient Broth (NB), kemudian diinkubasi pada suhu $37^{\circ} \mathrm{C}$ selama 24 jam.

Uji Aktivitas Antimikroba dari Isolat Cendawan Endofit Asal Tanaman Akar Wangi.

Uji aktivitas antimikroba dari cendawan endofit menggunakan metode sumuran. Candida albicans yang sudah ditumbuhkan pada media PDY cair selama 18-24 jam diambil menggunakan cutton bud. Selanjutnya di swab secara horizontal ke media PDY Agar dan dibiarkan selama 5 menit. Kemudian, media PDY Agar dilubangi dengan menggunakan sedotan steril yang berdiameter $6 \mathrm{~mm}$ sebanyak 3 sumuran percawan. Setiap sumuran diisi dengan $0,1 \mu 1$ dari hasil fermentasi cendawan endofit yang telah ditumbuhkan pada media PDB. Selanjutnya, diinkubasi pada suhu ruang dan diamati zona hambat yang terbentuk selama 2448 jam.

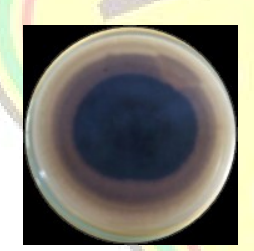

(a)

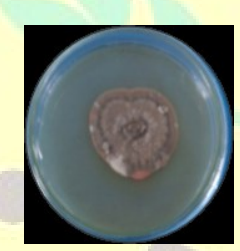

(b)

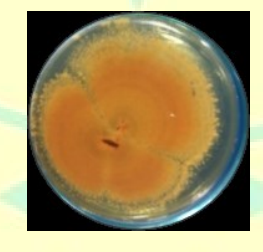

(c)

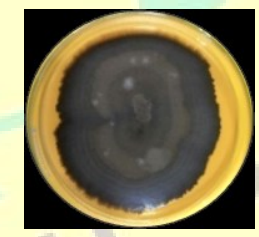

(d)

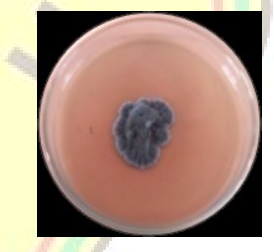

(e)

Gambar 3.1. Beberapa isolat cendawan endofit yang berhasil diisolasi dari tanaman akar wangi (Vetiveria zizanioides L.); (a) IH 4, (b) IH 9, (c) IH 14, (d) IH 17, dan (e) IH 26.

\section{Uji Aktivitas Antimikroba}

Hasil uji aktivitas antimikroba yang telah dilakukan, diperoleh 29 isolat cendawan endofit mampu menghambat pertumbuhan $S$. aureus, 30 isolat mampu menghambat $E$. coli dan 21 isolat menghambat pertumbuhan $C$. albicans (Tabel 3.1). 
Tabel 3.1. Uji Aktivitas Antimikroba dari Isolat Cendawan Asal Tanaman Akar Wangi (Vetiveria zizanioides L.)

\begin{tabular}{|c|c|c|c|c|c|c|}
\hline \multirow{2}{*}{ Isolat } & \multicolumn{6}{|c|}{ Zona hambat $(\mathrm{mm})$} \\
\hline & S. aureus & Kategori & E. coli & Kategori & C. albicans & Kategor \\
\hline $\mathrm{IH} 1$ & 9 & Sedang & 14 & Kuat & 12 & Kuat \\
\hline $\mathrm{IH} 2$ & 23 & Sangat kuat & 9 & Sedang & 4 & Lemah \\
\hline IH 3 & 13 & Kuat & 5 & Sedang & 6 & Medium \\
\hline $\mathrm{IH} 4$ & 20 & Sangat kuat & 9 & Sedang & 2 & Lemah \\
\hline IH 5 & - & - & 8 & Sedang & 8 & Medium \\
\hline IH 6 & 1 & Lemah & 15 & Kuat & - & - \\
\hline IH 7 & - & - & 22 & Sangat Kuat & 12 & Kuat \\
\hline $\mathrm{IH} 8$ & 6 & Sedang & 15 & Kuat & 13 & Kuat \\
\hline IH 9 & 21 & Sangat kuat & 12 & Kuat & - & - \\
\hline IH 10 & 19 & Kuat & 15 & Kuat & 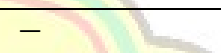 & - \\
\hline IH 11 & 21 & Sangat kuat & 13 & Kuat & +2 & - \\
\hline IH 12 & 5 & Sedang & - & - & - & - \\
\hline IH 13 & 4 & Lemah & 14 & Kuat & 4 & Lemah \\
\hline IH 14 & 2 & Lemah & - & - & - & - \\
\hline IH 15 & 21 & Sangat kuat & 14 & Kuat & 3 & Lemah \\
\hline IH 16 & 21 & Sangat kuat & - & - & $\theta$ & - \\
\hline IH 17 & 10 & Sedang & 5 & Sedang & - & - \\
\hline IH 18 & 2 & Lemah & 12 & Kuat & - & - \\
\hline IH 19 & 21 & Sangat kuat & 16 & Kuat & 19 & Kuat \\
\hline IH 20 & - & - & 21 & Sangat kuat & 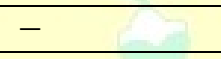 & - \\
\hline IH 21 & 21 & Sangat Kuat & 19 & Kuat & 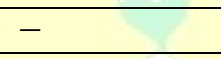 & - \\
\hline IH 22 & 3 & Lemah & 16 & Kuat & 5 & Medium \\
\hline IH 23 & 2 & Lemah & 12 & Kuat & 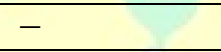 & - \\
\hline $\mathrm{IH} 24$ & 3 & Lemah & 14 & Kuat & 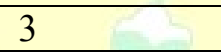 & Lemah \\
\hline IH 25 & 3 & Lemah & 16 & Kuat & 6 & Medium \\
\hline IH 26 & 2 & Lemah & 13 & Kuat & 5 & Medium \\
\hline IH 27 & 14 & Kuat & 14 & Kuat & 6 & Medium \\
\hline IH 28 & - & - & 14 & Kuat & 5 & Medium \\
\hline IH 29 & 9 & Sedang & 14 & Kuat & 19 & Kuat \\
\hline IH 30 & 5 & Sedang & 19 & Kuat & - & - \\
\hline IH 31 & 19 & Kuat & 11 & Kuat & 6 & Medium \\
\hline IH 32 & 6 & Sedang & 19 & Kuat & 6 & Medium \\
\hline IH 33 & 23 & Sangat kuat & 13 & Kuat & 2 & Lemah \\
\hline
\end{tabular}

Keterangan: -: tidak ada zona hambat

Berdasarkan tabel 3.1, zona hambat yang dihasilkan oleh isolat cendawan endofit terhadap S. aureus terdapat 4 isolat dengan kategori kuat yaitu isolat IH 3, IH 10, IH 27, dan IH 31; 9 isolat dengan kategori sangat kuat yaitu isolat $\mathrm{IH} 2, \mathrm{IH}$ 4, IH 9, IH 11, IH 15, IH 16, IH 19, IH 21, dan IH 33. Zona hambat yang dihasilkan oleh isolat cendawan endofit terhadap E. coli terdapat 23 isolat dengan kategori kuat yaitu isolat IH 1, IH 6, IH 8, IH 9, IH 10, IH 11, IH 13, IH 15, IH 18, IH 19, IH 21, IH 22, IH 23, IH 24, IH 25, IH 26, IH 27, IH 28, IH 29, IH 30, IH 31, IH 32, dan IH
33; 2 isolat dengan kategori sangat kuat yaitu isolat IH 7 dan IH 20. Sedangkan zona hambat yang dihasilkan oleh cendawan endofit terhadap C. albicans yang termasuk ke dalam kategori kuat yaitu isolat IH 1, IH 7, IH 8, IH 19 dan IH 29. Penghambatan antimikorba pada penelitian ini menggunakan pengkategorian dari Davis \& Stout (1971) yaitu untuk kategori lemah $(<5$ $\mathrm{mm})$, sedang $(5-10 \mathrm{~mm})$, kuat $(11-20 \mathrm{~mm})$ dan sangat kuat $(>20)$ berdasarkan diameter zona hambat yang diperoleh. 
Zona hambat yang terbentuk disekitar sumuran menunjukkan kemampuan dari isolat cendawan endofit tersebut dalam menghambat

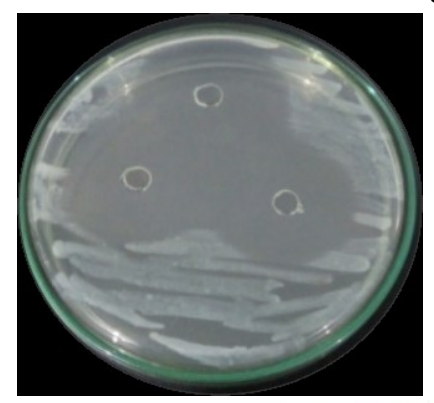

(a)

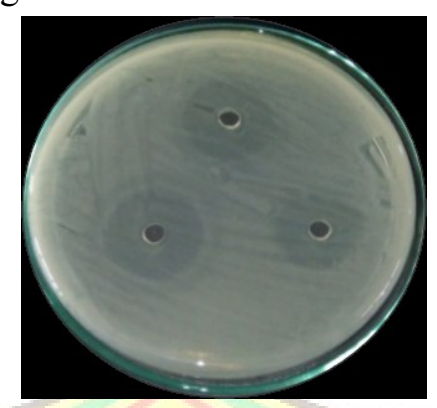

(b) pertumbuhan E.coli, S. aureus dan C.albicans (Gambar 3.2).

Gambar 3.2 Uji aktivitas antibakteri terhadap S.aureus (a), E.coli (b) dan C.albicans dengan metode difusi agar.

Pada pengujian antimikroba dengan hasil fermentasi isolat cendawan endofit diperoleh nilai zona hambat yang berbeda berdasarkan bakteri dan cendawan uji masing-masing. Frazier \& Westhoff (1988) menyatakan bahwa kemampuan suatu zat antimikroba dalam menghambat pertumbuhan mikroba dipengaruhi oleh berbagai faktor antara lain konsentrasi zat antimikroba, suhu lingkungan, waktu penyimpanan, sifat-sifat mikroba seperti (jenis, jumlah, umur dan keadaan mikroba), serta fisik dan kimia makanan termasuk kadar air, $\mathrm{pH}$, jenis dan jumlah senyawa di dalamnya.

Kemampuan antibakteri yang dihasilkan oleh isolat cendawan endofit berbeda-beda. Menurut Pelczar dan Chan (1998) semakin tinggi daya zat antibakteri yang dihasilkan, maka semakin tinggi daya hambat yang ditunjukkan dengan terbentuknya zona bening. Zona hambat tersebut menunjukkan aktivitas suatu senyawa antibakteri dalam menghambat pertumbuhan dan membunuh bakteri patogen.

Rata-rata hasil uji aktivitas antimikroba terbesar dari isolat cendawan endofit ditemukan pada $S$. aureus. Secara umum penghambatan lebih besar terhadap bakteri Gram positif yaitu $S$. aureus dibandingkan dengan bakteri Gram negatif $E$. coli, hal ini disebabkan karena struktur dinding sel bakteri Gram negatif lebih kompleks dibandingkan dengan bakteri Gram positif. Bakteri Gram positif memiliki peptidoglikan yang tidak terlindungi oleh membran luar (Navarre dan Schneewind 1999). Perbedaan struktur lapisan membran tersebut menyebabkan bakteri Gram negatif kurang sensitif terhadap antibakteri daripada bakteri Gram positif (Giguère et al., 2006). Menurut Fajrina et al. (2008), mekanisme penghambatan yang dilakukan oleh senyawa antibakteri dapat melalui beberapa cara yaitu kerusakan pada dinding sel, perubahan permeabilitas sel, dan menghambat sintesis protein dan asam nukleat. Banyak faktor dan keadaan yang dapat mempengaruhi kerja antibakteri, antara lain konsentrasi antibakteri, jumlah bakteri, spesies bakteri, adanya bahan organik, suhu, dan $\mathrm{pH}$ lingkungan.

Beberapa isolat yang tidak menghasilkan zona hambat, kemungkinan menghasilkan senyawa lain seperti pemberi warna atau pigmen, racun, agen pertumbuhan, pestisida (Demain, 1998) dan sebagai antikanker (Chandra, 2012). Menurut Tan \& Zou (2000), mikroba endofit dapat menghasilkan senyawa bioaktif yang karakternya mirip atau sama dengan inangnya. Hal ini disebabkan adanya pertukaran genetik yang terjadi antara inang dan mikroba endofit secara evolusioner.

\section{KESIMPULAN}

Berdasarkan penelitian tentang isolasi cendawan endofit dari tanaman akar wangi (Vetiveria zizanioides L.) dan uji aktivitas 
antimikroba terhadap E. coli, S. aureus dan $C$. albicans dapat disimpulkan bahwa hasil isolasi cendawan endofit dari tanaman akar wangi diperoleh 33 isolat. Uji aktivitas antifungi terhadap C. albicans diperoleh 20 isolat yang mampu menghambat pertumbuhan $C$. albicans, 29 isolat cendawan endofit mampu menghambat $S$. aureus dan 30 isolat mampu menghambat pertumbuhan E. coli.

Penelitian selanjutnya agar dapat melakukan penelitian untuk mengetahui jenisjenis senyawa kimia dari cendawan endofit asal tanaman akar wangi yang dapat menghambat pertumbuhan E. coli, S. aureus dan C. albicans sehingga dapat diproduksi dalam jumlah yang banyak dan melakukan identifikasi mikroskopis dan molekuler isolat cendawan endofit dari tanaman akar wangi yang potensial

\section{DAFTAR PUSTAKA}

Azevedo, J. L., W. Maccheroni Jr, J. O. Pereira., dan W. L. de Araujo. 2000. Endophytic microorganisms: a review on insect control and recent advances on tropical plants. Electronic Journal of Biotechnology 3:1.

Chandra, S. (2012). Endophytic fungi: novel sources of anticancer lead molecules. Appl Microbiol Biotechnol, 95, 47-59.

Choi, Y. W. I. J. Hodgkiss and K. D. Hyde. 2005. Enzyme production by endophytes of Brucea javanica. Journal of Agriculture Technology. 1: 55-65.

Departemen Kesehatan. 2015. Penggunaan Antibiotik Bijak dan Rasional Kurangi Beban Penyakit Infeksi. www.depkes.go.id . [18 April 2016]

Demain, A.L. (1998). Induction of microbial secondary metabolism. Internatl microbiol, 1, 259-264

Fajrina IH, Djamaludin AM, Habibie MS, Haratanti, Sari RF. 2008. Potensi Kitosan Sebagai Bahan Antibakteri. Laporan Akhir PKM, Institut Pertanian Bogor.

Giguere, S. Prescott J. F., Baggot J. D., Walkwer R. D., Dowling PM. 2006. Antimicrobial Therapy In Veterinary Medicine, 4th Ed. Blackwell Pubhlishing, Ames Lowa.
Hsiao Y, Hsun SC, Ta WL, Sung YH, Gwo FY, Ming JC, Ih SC. 2016. Secondary metabolite and bioactivity of the endophytic fungus Phomopsis theicola from Taiwanese endemic plant. Rec.Nat.Prod. 10(2):189-194

Lu H, Zou WX, Meng JC, Hu J, Tan RX. 2000. New Bioactive metabolites produced by Colletotrichum sp., an endophytic fungus in Artemisia annua. Plant Sci. 151:7673.

Martin RC, James ED. 2015. Isolation and Identification of Fungal Endophytes from Grasses along the Oregon Coast. American Journal of Plant Sciences. 6:3216-3230

Moffitt, B.A. Neilan. - Evolutionary Affiliation Within the Superfamily of Ketosynthases Reflect Complex Pathway Associationsll. J. Mol. Evol, vol. 56, pp. 446-457. 2002.

Okane I, Praset S, Kyoko T, Thomas L, Somsak S, Nigel HJ, Akira N, Wanchern P, Suzuki K. 2008. Study of endophytic Xylariaceae in Thailand: diversity and taxonomy inferred from rDNA sequence analyses with saprobes forming fruit bodies in the field. Mycoscience 49: 3593772.

Pelczar, M.J dan E.C.S. Chan. 1998. Elements of Microbiology. New York: McGrawHill Book Company, Inc diterjemahkan olehR.S..

Petrini O. 1991. Fungal endophytes of tree leaves. In Microbial ecology of leaves, Eds., J.H. Andrewsand S.S. Hirano. New York: Springer Verlag 179-197.

Petrini O, Thomas NS, Toti L, Viret O. 1992. Ecology, metabolite production and substrat utilization in endophytic fungi. Nat toxin. 1:185-196.

Ratha, M, Subha. K, Senthilkumar. G dan Panneerselvam.A. (2012). Screening of phytochemical and antibacterial activity of Hemidesmus indicus (L.) and Vetiveria zizanoides (L.). Europ J. Exp. Biol. 2(2): 363-368.

Santiago C, Fitchett C, Munro MHG, Jalil J, Santhanam. 2011. Cytotoxic and 
antifungal activities of 5Hydroxyramulosin, a compound produced by an endophytic fungus isolated from Cinnamomum mollisimum Evidence-Based complementary \& alternative medicine 2012:6

Soni A, Dahiya P. 2015. Screening of Phytochemicals and Antimicrobial Potential of Extracts of Vetiver zizanoides and Phragmtes karka Againts Clinical Isolates. Int. J. App. Pharm. 7

(1): $22-24$

Strobel G, Daisy B. 2003. Bioprospecting for Microbial Endophytes and Their Natural
Products. Microbiology and Molecular Biology Reviews; 67(4): 491-502.

Tan, RX, Zou WX. 2001. Endophytes: a rich source of funtional metabolites. Nat Prod Rep. 18:448-459.

Zinniel, D. K., P. Lambrecht, N. B. Haris, Z. Feng, D. Kuczmarski, P. Higley, C. A. Ishimaru, A. Arunakumari, R. G. Barletta, and A.K. Vidader. 2002. Isolat ion and characterization of endophytic colonizing bacteria from agronomics crops and prairie plants. Applied and Environmental Microbiology. 68 (5):2198-2208. 